\title{
Rare Case of Multiple Lineage Dysplasia Myelodysplastic Syndrome Presenting with Only Anemia: A Case Report
}

\author{
Noorwati Soetandyo ${ }^{1 *(\mathbb{D})}$, Ikhwan Rinaldi ${ }^{2}$, Resti Mulya Sari ${ }^{1}$, Agus Susanto Kosasih $^{3}$, Lyana Setiawan $^{3}$, Kevin Winston $^{4}$ \\ ${ }^{1}$ Department of Internal Medicine, Division of Hematology and Medical Oncology, Faculty of Medicine, Universitas Indonesia, \\ Dharmais National Cancer Hospital, Jakarta, Indonesia; ${ }^{2}$ Department of Internal Medicine, Division of Hematology and Medical \\ Oncology, Faculty of Medicine, Universitas Indonesia, Cipto Mangunkusumo National General Hospital, Jakarta, Indonesia; \\ ${ }^{3}$ Department of Clinical Pathology, Faculty of Medicine, Universitas Indonesia, Dharmais National Cancer Hospital, Jakarta, \\ Indonesia; ${ }^{4}$ Department of Internal Medicine, Faculty of Medicine, Universitas Indonesia, Cipto Mangunkusumo National \\ General Hospital, Jakarta, Indonesia
}

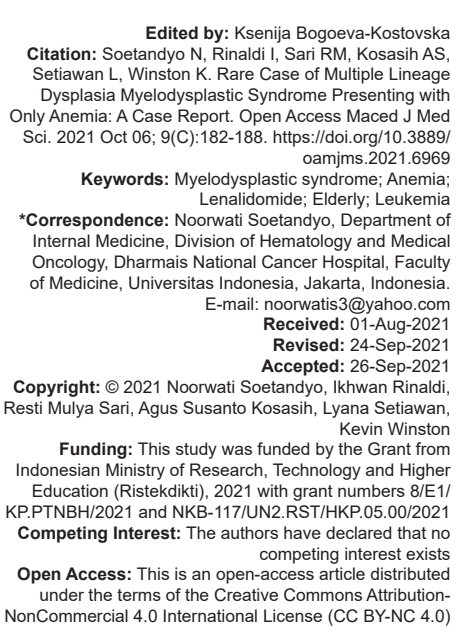

\section{Abstract}

BACKGROUND: Myelodysplastic syndrome (MDS) is a heterogeneous group of hematopoietic stem cell disorders which is characterized by ineffective hematopoiesis and risk of progression into acute myeloid leukemia. The diagnosis and classification of MDS are determined from the findings of dysplasia in one or more cell lineage and the percentage of blast cell on bone marrow examination. However, it should be noted that an abnormality in one marrow cell lineage does not necessarily translate to the corresponding clinical phenotype. Here, we present a case of MDS with multilineage dysplasia (MLD) (erythrocyte, leukocyte, and thrombocyte) from bone marrow aspiration, but with anemia as the sole clinical manifestation (single cytopenia).

CASE REPORT: A 78-year-old male patient came to our clinic on July 10, 2020, with chief complaint of worsening fatigue which started approximately 1 year before visit. His vital signs during the visit were stable and no othe abnormalities observed other than pale conjunctivae. Complete blood count showed macrocytic anemia with no abnormalities in leukocyte count and thrombocyte count, which suggested a single cytopenia. Peripheral blood smear was negative for megaloblasts and hypersegmented neutrophils. The patient's bone marrow examination showed MDS with MLD. This result was in contrast to complete blood count examination which only showed anemia (single cytopenia).

CONCLUSION: This case showed that there could be discrepancy between clinical manifestations of the cytopenia with bone marrow dysplasia, which highlighted the importance of conducting bone marrow examination to properly classify MDS type.

\section{Introduction}

Myelodysplastic syndrome (MDS) is a heterogeneous group of hematopoietic stem cell disorders which is characterized by ineffective hematopoiesis and risk of progression into acute myeloid leukemia [1], [2]. The ineffective hematopoiesis can occur in one or more cell types (red blood cells, white blood cells, and platelets) [2], [3], [4]. Interestingly, MDS has a wide range of clinical phenotypes with some patients remain asymptomatic while others express aggressive phenotype that quickly progress into refractory leukemia [2], [4], [5].

MDS has a tendency to occur in the elderly. Studies by $\mathrm{Ma}$ and Sekeres et al. reported age at presentation of 70 years or older [6], [7]. Furthermore, it is rarely diagnosed in people under 50 years old and is more common in males [8], [9].

The latest World Health Organization (WHO) classification of MDS was published in 2016 and served as a guideline for clinicians [10]. Here, classification of MDS is based from dysplasia in one or more cell lineage and percentage of blast cell on bone marrow examination [10]. However, it should be noted that an abnormality in one marrow cell lineage does not necessarily translate to the corresponding clinical phenotype [11], [12]. Here, we present a case of MDS with multilineage dysplasia (MLD) (erythrocyte, leukocyte, and thrombocyte) from bone marrow aspiration, but with anemia as the sole clinical manifestation (single cytopenia).

\section{Case Presentation}

A 78-year-old male patient came to our clinic on July 10, 2020, with chief complaint of worsening fatigue which started approximately 1 year before visit. No other complaints or symptoms were observed at that 
time. A medical and familial history was insignificant. His diet was nutritionally adequate. There was also no significant history of exposure to toxic agents or chemotherapy. His vital signs during the visit were stable and no other abnormalities observed other than pale conjunctivae.

Table 1: Laboratory data on July 10, 2020

\begin{tabular}{|c|c|c|}
\hline Parameter (units) & Result & Reference range, adults \\
\hline Hemoglobin $(\mathrm{g} / \mathrm{dL})$ & 7.9 & $13.2-17.3$ \\
\hline Hematocrit $(\%)$ & $22 \%$ & $40-52 \%$ \\
\hline Erythrocytes $\left(\times 10^{12} / \mathrm{L}\right)$ & 2.01 & $4.4-5.9$ \\
\hline Mean corpuscular volume (fL) & 108 & $80-100$ \\
\hline $\mathrm{MCH}(\mathrm{pg})$ & 41 & $26-34$ \\
\hline $\mathrm{MCHC}(\mathrm{g} / \mathrm{dL})$ & 38 & $32-36$ \\
\hline Reticulocyte (\%) & 1.8 & $0.5-1.5$ \\
\hline Corrected reticulocyte count (\%) & 0.99 & $0.5-1.5$ \\
\hline Absolute reticulocyte count $\left(\times 10^{6} / \mathrm{L}\right)$ & 36.1 & $20-75$ \\
\hline WBC $\left(\times 10^{9} / L\right)$ & 5.1 & $4.5-11$ \\
\hline Basophil (\%) & 1 & $0-1$ \\
\hline Eosinophil (\%) & 3 & $2-4$ \\
\hline Band neutrophil (\%) & 0 & $3-5$ \\
\hline Segmented neutrophil (\%) & 68 & $50-70$ \\
\hline Lymphocyte (\%) & 19 & $25-40$ \\
\hline Monocyte (\%) & 9 & $2-8$ \\
\hline Platelet $\left(\times 10^{9} / \mathrm{L}\right)$ & 298 & $150-440$ \\
\hline Bleeding time (minutes) & 3 & $0-6$ \\
\hline Prothrombin time (seconds) & 10.6 & $9.3-11.4$ \\
\hline Activated partial thromboplastin time (seconds) & 31.7 & $11-47$ \\
\hline Total protein $(\mathrm{g} / \mathrm{dL})$ & 6.8 & $6.6-8.8$ \\
\hline Albumin $(\mathrm{g} / \mathrm{dL})$ & 3.8 & $3.5-5.2$ \\
\hline Globulin ( $\mathrm{g} / \mathrm{dL})$ & 3 & $2.3-3.5$ \\
\hline AST $(U / L)$ & 26 & $<35$ \\
\hline ALT (U/L) & 24 & $<41$ \\
\hline Creatinine $(\mathrm{mg} / \mathrm{dL})$ & 1.5 & $0.9-1.3$ \\
\hline Estimated glomerular filtration rate* $\left(\mathrm{ml} / \mathrm{min} / 1.73 \mathrm{~m}^{2}\right)$ & $44-51$ & - \\
\hline
\end{tabular}

Complete blood count and iron studies were performed on July 10, 2020, and July 11, 2020, and the results are shown in Tables 1 and 2, respectively. Macrocytic anemia was observed based on the low hemoglobin level and increased mean corpuscular volume (MCV). Vitamin B12 level was observed to be elevated $(2768 \mathrm{pg} / \mathrm{mL})$. No abnormalities were observed in leukocyte count and thrombocyte count, which suggested a single cytopenia. The patient had slightly elevated creatinine. Furthermore, the liver function tests were normal. As a result, bone marrow examination was considered for additional examination to confirm the etiology of macrocytic anemia but the patient declined. The patient was then scheduled for packed red cell (PRC) transfusion to increase hemoglobin level.

Table 2: Iron studies and Vitamin B12 data on July 11, 2020

\begin{tabular}{lll}
\hline Parameter (units) & Result & Reference range, adults \\
\hline Serum iron (mcg/dL) & 152 & $65-175$ \\
Total iron-binding capacity $(\mathrm{mcg} / \mathrm{dL})$ & 181 & $250-425$ \\
Ferritin $(\mathrm{ng} / \mathrm{mL})$ & 395.77 & $21.81-274.66$ \\
Vitamin B12 $(\mathrm{pg} / \mathrm{mL})$ & 2768 & $187-883$ \\
\hline
\end{tabular}

On September 4, 2020, the patient returned for a routine check-up and complete blood count was performed. The result showed some improving parameters: Hemoglobin level of $9.6 \mathrm{~g} / \mathrm{dL}$, hematocrit $26 \%$, and RBC count $2.45 \times 10^{12} / \mathrm{L}$. Peripheral blood smear showed anisocytosis and macrocytic anemia without the presence of megaloblasts and hypersegmented neutrophils. Ferritin level increased to $641.73 \mathrm{ng} / \mathrm{ml}$. Additional examination such as the direct and indirect Coombs' tests was negative. Stool examination showed no sign of occult bleeding as well as infections or parasitic infestation. The patient was then advised again to take bone marrow aspiration examination.

Bone marrow aspiration was conducted on February 22, 2021 (Table 3). Morphological assessment of bone marrow revealed normal cellularity. Other findings included increased erythropoiesis with dyserythropoiesis and increased granulopoiesis with shift to left. Blast cell percentage was within normal limit $(0.5 \%)$. Thrombopoiesis was decreased with signs of dysmegakaryopoiesis. Based on the marrow morphological examinations, a diagnosis of MDS with MLD was established.

Table 3: Bone marrow examination on February 22, 2021

\begin{tabular}{lll}
\hline Parameter (units) & Result & Reference range, adults \\
\hline Marrow cellularity & Normal & Normal \\
Marrow adipose tissue & Normal & Normal \\
Blast (\%) & 0.5 & $0.1-1.1$ \\
Progranulocyte (\%) & 1 & - \\
Myelocyte (\%) & 14 & $2.6-13.5$ \\
Metamyelocyte (\%) & 6.5 & $5-20.8$ \\
Band neutrophil (\%) & 4.5 & $10.8-20.4$ \\
Segmented neutrophil (\%) & 23.5 & $7-37.8$ \\
Basophil (\%) & 1 & $0-0.6$ \\
Eosinophil (\%) & 1 & $0.4-4.4$ \\
Rubriblast (\%) & 1 & $0-1$ \\
Prorubriblast (\%) & 3 & $0.1-3.2$ \\
Rubricyte (\%) & 10.5 & $4.2-12.8$ \\
Metarubricyte (\%) & 17.5 & $6.6-33.4$ \\
Total myeloid (\%) & 51 & - \\
Total erythroid (\%) & 32 & - \\
Myeloid-erythroid ratio & $1.6: 1$ & - \\
Megakaryocyte count & Increased & Normal \\
Abnormal morphology & Dysthrombopoiesis observed & - \\
Thrombocyte formation & Reduced & - \\
\hline
\end{tabular}

Immunophenotyping from the bone marrow showed no dominant immunophenotype marker. Cytogenetic examination showed nonrandom karyotype abnormalities of chromosome 7 deletion, trisomy 13, and trisomy 22 which correspond to poor prognosis based on cytogenetic risk group from revised international prognostic scoring system (IPSS-R) cytogenetic risk group [13].

The patient was then treated with lenalidomide to increase hemoglobin and induce transfusion independence. However, no response was observed after a few months of therapy and subsequently, treatment was switched to erythropoietin (EPO) supplementation which also showed no response. The patient was subsequently given supportive treatment and periodic transfusions.

\section{Discussion}

MDSs are clonal hematopoietic disorders which have variable clinical course and prognosis [4], [14]. The symptoms of MDS are often related to the chronic unexplained cytopenia. For example, MDS patients may have symptoms of fatigue caused by anemia, bleeding if thrombocytopenic, and infection in leukopenia [14]. Anemia is the most common cytopenia in MDS, however, many patients can be asymptomatic, 
especially in early stage MDS [15]. Therefore, the diagnosis of MDS can be challenging for clinicians due to lack of specific symptoms.

\section{Diagnosis of MDS presenting with anemia}

For patients presenting with anemia, a careful previous medical history and physical examination must be obtained to exclude possible causes of iron deficient anemia, anemia of chronic disease, and hemolytic anemia. Routine laboratory examinations consisting of complete blood count, iron studies, reticulocyte count, peripheral blood smear, and Vitamin B9/B12 must also be conducted to exclude common causes of anemia [2], [4], [5]. History of toxic exposure to benzene, chemotherapy, and pesticides should be checked since these can increase risk of MDS. Thus, other possible causes of anemia should be excluded first before clinical suspicion of MDS is made.

The anemia in MDS is often macrocytic, although occasionally it may also present as normocytic anemia [15], [16], [17]. The MCV in this patient was elevated which suggested macrocytic anemia. In our case, the peripheral blood smear was negative for megaloblasts and hypersegmented neutrophils, which supported the diagnosis of non-megaloblastic anemia. Further supporting the non-megaloblastic anemia was the elevated Vitamin B12 level in this patient. Several causes of non-megaloblastic anemia are alcohol abuse, liver disease, MDS, and congenital bone marrow failure syndromes [18]. In this patient, there was no history of alcohol abuse and the symptoms of anemia never occurred previously. In addition, the liver function tests were normal. Finally, the corrected reticulocyte count was normal, suggesting a pathological process in bone marrow. Thus, MDS remained as a possible cause of the macrocytic non-megaloblastic anemia in this patient.

The patient's bone marrow examination showed MDS with MLD. This result was in contrast to complete blood count examination which only showed anemia (single cytopenia). The findings of dysgranulopoiesis and dysthrombopoiesis from the bone marrow did not manifest as leukopenia and thrombocytopenia. Therefore, this case showed that there could be discrepancy between clinical manifestations of the cytopenia with bone marrow dysplasia, which highlighted the importance of conducting bone marrow examination to properly classify MDS type.

\section{Ferritin in MDS}

Patients with MDS often have elevated serum ferritin due to periodic transfusion [19]. Nonetheless, elevated serum ferritin can also be observed in MDS patients before transfusion which may occur due to ineffective erythropoiesis resulting in unused iron [20], [21]. Hence, serum ferritin may be useful to help diagnosing MDS since elevated serum ferritin in anemia could suggest the presence of dyserythropoiesis which may be attributed to bone marrow abnormalities. A recent study by Kikuchi et al. showed that serum ferritin level at diagnosis correlated with survival time and leukemia-free survival for MDS [22].

\section{Role of cytogenetic in MDS}

Cytogenetic examination of the bone marrow is an important diagnostic modality in MDS as evidenced by its incorporation in the WHO classification for risk stratification [10]. The study by Haase et al. with sample size of 2124 MDS patients showed that more than $50 \%$ of patients had cytogenetic abnormalities using standard karyotyping [23]. However, standard karyotyping technique has a limitation of being unable to detect cryptic chromosomal aberrations such as microdeletions and copy number neutral loss of heterozygosity. On the other hand, new techniques for cytogenetic analysis consisting of fluorescence in situ hybridization and single-nucleotide polymorphism arrays revealed that cryptic chromosomal aberrations can be observed in some MDS patients [24], [25].

It is interesting to note that in contrast to other hematological cancers where chromosomal translocations and inversions are dominant, MDS has higher number of chromosomal deletions and duplications [26]. There are many frequent cytogenetic abnormalities observed in MDS such as del(5q), del(20q), trisomy 8, and monosomy 7 [24], [26], [27].

MDS with $\operatorname{del}(5 q)$ presents such important prognostic value that in the latest WHO guideline, it is classified as a unique type MDS due to high response rate to lenalidomide therapy [2], [10], [28]. Around 30\% of MDS cases have del(5q), which also means that only around up to $30 \%$ of MDS patients theoretically have good response to lenalidomide [23], [28], [29]. The reason for this phenomenon is mainly caused by haploinsufficiency of multiple genes due to deletion in chromosome 5 region, in particular, haploinsufficiency of casein kinase 1 alpha 1 (CSNK1A1) gene which produces casein kinase 1A1 [30], [31]. Due to haploinsufficiency of CSNK1AI resulting in decreased expression of casein kinase, the cells become vulnerable to further reduction in casein kinase expression, which can be induced by lenalidomide through degradation of CSNK1Al through ubiquitination [32]. Hence, normal hematopoiesis is restored by suppression of clonal cells with del(5q). In contrast, normal cells with two copies of CSNK1A1 can tolerate the degradation of CSNK1AI by lenalidomide due to higher amount of CSNK1AI.

The cytogenetic abnormality of $\operatorname{del}(20 q)$ is associated with good prognosis in MDSs [13]. The reasons for this come from observation that de novo MDS patients with isolated $\operatorname{del}(20 \mathrm{q})$ have a tendency for indolent clinical course [33], [34]. However, the patients often have thrombocytopenia [35]. 
Monosomy of chromosome 7 indicates a poor prognosis [13], [36]. On the other hand, isolated del(7q) confers better prognosis [37]. The exact pathophysiology on how monosomy of chromosome 7 confers a poor prognosis is still incompletely understood but it is suspected that genes in chromosome 7 such as MLL3 may play a role [37], [38]. Other cytogenetic abnormalities are also observed in MDS but their significance is still unknown.

\section{Role of revised international prognostic scoring system for MDSs}

The WHO classification for MDS does not confer prognosis information which limits its utility in clinical setting. At present, one of the widely used scoring systems for MDS to determine prognosis is IPSS-R, introduced in the year 2012 [13]. The scoring system by IPSS-R uses cytogenetics, bone marrow blast, hemoglobin, platelets, and absolute neutrophil count. However, it should be noted that the estimated medical survival times in IPSS-R are based on untreated MDS patients [13]. Hence, the median survival times for treated MDS patients, irrespective of the prognosis based on IPSS-R may be longer. The main limitation of IPSS-R is lack of comorbidities incorporation for the prognosis, especially since MDS is a disease of the elderly that tend to have multiple comorbidities. Additional limitation is that the scoring system does not include serum ferritin and lactate dehydrogenase for prognosis of MDS patients despite several studies have shown the prognostic role for both of these variables [22], [39], [40].

In the case presented here, the patient showed multiple karyotype abnormalities involving chromosome 7 deletion, trisomy 13, and trisomy 22, which according to IPSS-R, this patient was grouped into poor prognostic subgroup on the MDS cytogenetic scoring system [13]. The cytogenetic subgroup's result was then combined with the laboratory data, resulting IPSS score of 4.5 which correspond to a high-risk category.

\section{Selecting treatment for MDS}

The choice of MDS treatment is determined mostly by risk stratification from IPSS-R, with higherrisk MDS given more aggressive active treatment than patients with lower-risk MDS [2]. However, prognostic risk should not be the sole factor to determine treatments. For example, caution should be exercised in elderly patient with higher-risk MDS when considering hypomethylating agents or chemotherapy as treatments. Benefits and risks must be weighted and discussed with the patient. Another example is consideration to provide stem cell transplantation in young patients with lower-risk MDS with the purpose to achieve highest survival possible.

\section{Anemia management in MDS}

There are three main treatment modalities that can be used for anemia: (1) Periodic PRC transfusion, (2) periodic erythropoiesis-stimulating agents (ESAs) injections, and (3) lenalidomide [2], [4].

Routine use of PRC transfusion can alleviate the symptoms of anemia, especially in patients with hemoglobin below $8 \mathrm{mg} / \mathrm{dL}$ [41], [42]. However, some patients such as older MDS patients may receive benefit from more liberal threshold as shown in an exploratory clinical trial by Stanworth et al. [42]. In the study, quality of life was significantly improved in the liberal group $(10.5 \mathrm{mg} / \mathrm{dL})$ when compared with the restrictive group (8 $\mathrm{mg} / \mathrm{dL})$. Nevertheless, routine transfusion is not recommended and should be avoided if possible due to the associated risks from transfusion such as iron accumulation, infection, and transfusion reactions. As a matter of fact, routine transfusion is a predictor for worse outcome in MDS [43].

A strategy to reduce transfusion dependence is using ESAs. Many studies have shown that a significant percentage of patients responded to ESAs supplementation and achieved hemoglobin improvement [4], [44], [45], [46]. One of the predictors for ESAs response is pre-treatment serum EPO levels of $<500 \mathrm{U} / \mathrm{L}$ [47]. Hence, pre-treatment EPO should be measured to determine MDS patients that can benefit from ESAs. However, use of ESAs can also be considered in patients with EPO of $\geq 500 \mathrm{U} / \mathrm{L}$ as some patients may still respond to the treatment [2], [44], [47].

Lenalidomide can also be used to achieve transfusion independence, however, as stated above, the predictor for lenalidomide response is presence of del(5q) [28], [32]. If given to population of MDS patients without del $(5 q)$, only around $26.9 \%$ of patients achieved transfusion independence [48]. Furthermore, the response is usually short-lived.

In our patient, lenalidomide was given despite the patient not having del(5q). The reason for this was the old age of the patient where periodic transfusion should be avoided if possible. Furthermore, despite being higher-risk MDS, we did not give intensive chemotherapy or hypomethylating agents due to side effects which might be detrimental for the patient such as infection.

After treatment with lenalidomide, no improvement was observed. The patient was then given ESAs supplementation but similarly, no response was observed. Unfortunately, we did not measure pre-treatment serum EPO level before ESAs, hence, whether the ESAs failure was due to already elevated serum EPO or other causes could not be determined. 


\section{Conclusion}

Diagnosing MDS is very challenging and requires comprehensive clinical and laboratory assessment. Bone marrow examination plays an important role in determining lineage dysplasia as clinical cytopenia does not always come in line. Cytogenetic analysis helps in determining prognosis of MDS patients. Treatments for anemia in MDS consisted of periodic PRC transfusion, periodic ESAs injections, and lenalidomide.

\section{Statement of Ethics}

Oral informed consent was obtained from the patient for publication of this case report.

\section{Authors' Contributions}

IR and NS were the physicians who treated the patient in this report. LS and ASK provided cytogenetic interpretation of the patient. The manuscript was prepared by IR, NS, KW, and LS. All authors participated in discussions about the manuscript and approved the final version.

\section{References}

1. Fontenay M, Farhat B, Boussaid I. Pathophysiology of myelodysplastic syndromes. Hemato. 2021;2:477-95.

2. Cazzola M. Myelodysplastic syndromes. N Engl J Med 2020;383(14):1358-74. http://doi.org/10.1056/NEJMra1904794 PMid:32997910

3. Gangat N, Patnaik MM, Tefferi A. Myelodysplastic syndromes: Contemporary review and how we treat. Am J Hematol. 2016;91(1):76-89. http://doi.org/10.1002/ajh.24253 PMid:26769228

4. Malcovati L, Hellström-Lindberg E, Bowen D, Adès L, Cermak J, Del Cañizo $\mathrm{C}$, et al. Diagnosis and treatment of primary myelodysplastic syndromes in adults: Recommendations from the European LeukemiaNet. Blood. 2013;122(17):2943-64. http://doi.org/10.1182/blood-2013-03-492884

PMid:23980065

5. Samiev D, Bhatt VR, Armitage JD, Maness LJ, Akhtari M. A primary care approach to myelodysplastic syndromes. Korean J Fam Med. 2014;35(3):111-8. http://doi.org/10.4082/ kjfm.2014.35.3.111 PMid:24921029

6. $\mathrm{Ma} \mathrm{X}$. Epidemiology of myelodysplastic syndromes. Am J Med 2012;125(7 Suppl):S2-5. http://doi.org/10.1016/j. amjmed.2012.04.014

PMid:22735748

7. Sekeres MA, Schoonen WM, Kantarjian $H$, List $A$, Fryzek J, Paquette R, et al. Characteristics of US patients with myelodysplastic syndromes: Results of six crosssectional physician surveys. $\mathrm{JNCl} J$ Natl Cancer Inst. 2008;100(21):1542-51. http://doi.org/10.1093/jnci/djn349 PMid: 18957672

8. Marisavljevic D, Savic A, Zeremski V, Stanisavljevic N, Jelic $\mathrm{S}$. Myelodysplastic syndromes in adults aged less than 50 years: Incidence and clinicopathological data. J BUON 2014;19(4):999-1005.

PMid:25536608

9. Ma X, Does M, Raza A, Mayne ST. Myelodysplastic syndromes: Incidence and survival in the United States. Cancer. 2007;109(8):1536-42. http://doi.org/10.1002/cncr.22570 PMid: 17345612

10. Arber DA, Orazi A, Hasserjian R, Thiele J, Borowitz MJ, Le Beau MM, et al. The 2016 revision to the World Health Organization classification of myeloid neoplasms and acute leukemia. Blood. 2016;127(20):2391-405. http://doi. org/10.1182/blood-2016-03-643544 PMid:27069254

11. Maassen A, Strupp C, Giagounidis A, Kuendgen A, Nachtkamp K Hildebrandt $\mathrm{B}$, et al. Validation and proposals for a refinement of the WHO 2008 classification of myelodysplastic syndromes without excess of blasts. Leuk Res. 2013;37(1):64-70. http://doi. org/10.1016/j.leukres.2012.09.021

PMid:23122806

12. Germing U, Strupp C, Giagounidis A, Haas R, Gattermann N, Starke $\mathrm{C}$, et al. Evaluation of dysplasia through detailed cytomorphology in 3156 patients from the Düsseldorf Registry on myelodysplastic syndromes. Leuk Res. 2012;36(6):727-34. http://doi.org/10.1016/j.leukres.2012.02.014 PMid:22421409

13. Greenberg PL, Tuechler H, Schanz J, Sanz G, Garcia-Manero G, Solé $\mathrm{F}$, et al. Revised international prognostic scoring system for myelodysplastic syndromes. Blood. 2012;120(12):2454-65. http://doi.org/10.1182/blood-2012-03-420489 PMid:22740453

14. Foran JM, Shammo JM. Clinical presentation, diagnosis, and prognosis of myelodysplastic syndromes. Am J Med. 2012;125(7 Suppl):S6-13. http://doi.org/10.1016/j. amjmed.2012.04.015 PMid:22735753

15. Barzi A, Sekeres MA. Myelodysplastic syndromes: A practical approach to diagnosis and treatment. Cleve Clin J Med. 2010;77(1):37-44. http://doi.org/10.3949/ccjm.77a.09069 PMid:20048028

16. Nagao T, Hirokawa M. Diagnosis and treatment of macrocytic anemias in adults. J Gen Fam Med. 2017;18(5):200-4. PMid:29264027

17. Nguyen PL. The myelodysplastic syndromes. Hematol Oncol Clin North Am. 2009;23(4):675-91. http://doi.org/10.1016/j. hoc.2009.04.008 PMid:19577164

18. Aslinia F, Mazza JJ, Yale SH. Megaloblastic anemia and other causes of macrocytosis. Clin Med Res. 2006;4(3):236-41. http:// doi.org/10.3121/cmr.4.3.236 PMid:16988104

19. Pileggi C, Di Sanzo M, Mascaro V, Marafioti MG, Costanzo FS, Pavia M. Role of serum ferritin level on overall survival in patients with myelodysplastic syndromes: Results of a meta-analysis of observational studies. PLoS One. 2017;12(6):e0179016. http:// 
doi.org/10.1371/journal.pone.0179016

PMid:28622367

20. Cortelezzi A, Cattaneo C, Cristiani S, Duca L, Sarina B, Deliliers GL, et al. Non-transferrin-bound iron in myelodysplastic syndromes: A marker of ineffective erythropoiesis? Hematol J. 2000;1(3):153-8. http://doi.org/10.1038/sj.thj.6200028 PMid:11920184

21. Kim A, Nemeth $E$. New insights into iron regulation and erythropoiesis. Curr Opin Hematol. 2015;22(3):199-205. http:// doi.org/10.1097/MOH.0000000000000132

PMid:25710710

22. Kikuchi S, Kobune M, lyama S, Sato T, Murase K, Kawano $\mathrm{Y}$, et al. Prognostic significance of serum ferritin level at diagnosis in myelodysplastic syndrome. Int J Hematol. 2012;95(5):527-34. http://doi.org/10.1007/s12185-012-1048-3 PMid:22407873

23. Haase D, Germing U, Schanz J, Pfeilstöcker M, Nösslinger T, Hildebrandt B, et al. New insights into the prognostic impact of the karyotype in MDS and correlation with subtypes: Evidence from a core dataset of 2124 patients. Blood. 2007;110(13):4385-95. http://doi.org/10.1182/blood-2007-03-082404

PMid: 17726160

24. Anastasi J, Feng J, Le Beau MM, Larson RA, Rowley JD, Vardiman JW. Cytogenetic clonality in myelodysplastic syndromes studied with fluorescence in situ hybridization: Lineage, response to growth factor therapy, and clone expansion. Blood. 1993;81(6):1580-5.

PMid:8453104

25. Gondek LP, Tiu R, O'Keefe CL, Sekeres MA, Theil KS, Maciejewski JP. Chromosomal lesions and uniparental disomy detected by SNP arrays in MDS, MDS/MPD, and MDS-derived AML. Blood. 2008;111(3):1534-42. http://doi.org/10.1182/ blood-2007-05-092304

PMid: 17954704

26. Zahid MF, Malik UA, Sohail M, Hassan IN, Ali S, Shaukat MH, et al. Cytogenetic abnormalities in myelodysplastic syndromes: An overview. Int J Hematol Oncol Stem Cell Res. 2017;11(3):231-9.

PMid:28989590

27. Kawankar N, Vundinti BR. Cytogenetic abnormalities in myelodysplastic syndrome: An overview. Hematology. 2011;16(3):131-8. $11 \times 12940641877966$

PMid:21669051

28. List A, Dewald G, Bennett J, Giagounidis A, Raza A, Feldman E, et al. Lenalidomide in the myelodysplastic syndrome with chromosome 5q deletion. N Engl J Med. 2006;355(14):1456-65. http://doi.org/10.1056/NEJMoa061292

PMid:17021321

29. Giagounidis A a. N, Germing U, Haase S, Hildebrandt B, Schlegelberger B, Schoch C, et al. Clinical, morphological, cytogenetic, and prognostic features of patients with myelodysplastic syndromes and del(5q) including band q31. Leukemia. 2004;18(1):113-9. http://doi.org/10.1038/sj.leu.2403189 PMid:14586479

30. Ebert BL, Pretz J, Bosco J, Chang CY, Tamayo P, Galili N, et al. Identification of RPS14 as a 5q- syndrome gene by RNA interference screen. Nature. 2008;451(7176):335-9.

PMid: 18202658

31. Schneider RK, Ademà V, Heckl $D$, Järås $M$, Mallo $M$, Lord $A M$, et al. Role of casein kinase $1 \mathrm{~A} 1$ in the biology and targeted therapy of del(5q) MDS. Cancer Cell. 2014;26:509-20. http:// doi.org/10.1016/j.ccr.2014.08.001

PMid:25242043
32. Fink EC, Ebert BL. The novel mechanism of lenalidomide activity. Blood. 2015;126(21):2366-9. http://doi.org/10.1182/ blood-2015-07-567958

PMid:26438514

33. Gupta R, Soupir CP, Johari V, Hasserjian RP. Myelodysplastic syndrome with isolated deletion of chromosome 20q: An indolent disease with minimal morphological dysplasia and frequent thrombocytopenic presentation. $\mathrm{Br} \mathrm{J}$ Haematol. 2007;139(2):265-8.

PMid: 17764468

34. Braun T, de Botton S, Taksin AL, Park S, Beyne-Rauzy O, Coiteux V, et al. Characteristics and outcome of myelodysplastic syndromes (MDS) with isolated 20q deletion: A report on 62 cases. Leuk Res. 2011;35(7):863-7. http://doi.org/10.1016/j. leukres.2011.02.008

PMid:21396711

35. Bacher $\mathrm{U}$, Haferlach $\mathrm{T}$, Schnittger $\mathrm{S}$, Zenger M, Meggendorfer $\mathrm{M}$, Jeromin S, et al. Investigation of 305 patients with myelodysplastic syndromes and $20 \mathrm{q}$ deletion for associated cytogenetic and molecular genetic lesions and their prognostic impact. $\mathrm{Br} J$ Haematol. 2014;164(6):822-33. http://doi.org/10.1111/bjh.12710 PMid:24372512

36. Kere J, Ruutu T, de la Chapelle A. Monosomy 7 in granulocytes and monocytes in myelodysplastic syndrome. N Engl J Med. 1987;316(9):499-503. http://doi.org/10.1056/ NEJM198702263160902

PMid:2880296

37. Cordoba I, González-Porras JR, Nomdedeu B, Luño E, de Paz R, Such E, et al. Better prognosis for patients with del(7q) than for patients with monosomy 7 in myelodysplastic syndrome. Cancer. 2012;118(1):127-33. http://doi.org/10.1002/cncr.26279 PMid:21717439

38. Chen C, Liu Y, Rappaport AR, Kitzing T, Schultz N, Zhao Z, et al. MLL3 is a haploinsufficient $7 q$ tumor suppressor in acute myeloid leukemia. Cancer Cell. 2014;25(5):652-65. http://doi. org/10.1016/j.ccr.2014.03.016

PMid:24794707

39. Wimazal F, Sperr WR, Kundi M, Meidlinger P, Fonatsch $C$ Jordan JH, etal. Prognosticvalue of lactate dehydrogenaseactivity in myelodysplastic syndromes. Leuk Res. 2001;25(4):287-94. http://doi.org/10.1016/s0145-2126(00)00140-5

PMid: 11248325

40. Morita K, Arai S, Kogure Y, Honda A, Nakazaki K, Kurokawa M. Serum LDH is useful to predict prognosis for intermediate-risk myelodysplastic syndrome. Blood. 2015;126:5255. https://doi. org/10.1182/blood.V126.23.5255.5255

41. Cazzola M, Della Porta MG, Malcovati L. Clinical relevance of anemia and transfusion iron overload in myelodysplastic syndromes. Hematol Am Soc Hematol Educ Program. 2008;1:166-75. https://doi.org/10.1182/ asheducation-2008.1.166

PMid: 19074076

42. Stanworth SJ, Killick S, McQuilten ZK, Karakantza M, Weinkove R, Smethurst H, etal. Red cell transfusion in outpatients with myelodysplastic syndromes: A feasibility and exploratory randomised trial. Br J Haematol. 2020;189(2):279-90. https:// doi.org/10.1111/bjh.16347

PMid:31960409

43. Malcovati L. Impact of transfusion dependency and secondary iron overload on the survival of patients with myelodysplastic syndromes. Leuk Res. 2007;31(Suppl 3):S2-6. https://doi. org/10.1016/S0145-2126(07)70459-9

PMid: 18037415

44. Bessho M, Jinnai I, Matsuda A, Saito M, Hirashima K. Improvement of anemia by recombinant erythropoietin in 
patients with myelodysplastic syndromes and aplastic anemia. Int J Cell Cloning. 1990;8(6):445-58. https://doi.org/10.1002/ stem. 5530080647

PMid:2273298

45. Mantovani L, Lentini G, Hentschel B, Wickramanayake PD, Loeffler $\mathrm{M}$, Diehl $\mathrm{V}$, et al. Treatment of anaemia in myelodysplastic syndromes with prolonged administration of recombinant human granulocyte colony-stimulating factor and erythropoietin. $\mathrm{Br} J$ Haematol. 2000;109(2):367-75. https://doi. org/10.1046/j.1365-2141.2000.02016.x

PMid: 10848827

46. Fenaux P, Santini V, Spiriti MA, Giagounidis A, Schlag R, Radinoff $A$, et al. A phase 3 randomized, placebo-controlled study assessing the efficacy and safety of epoetin- $\alpha$ in anemic patients with low-risk MDS. Leukemia. 2018;32(12):2648-58. https://doi.org/10.1038/s41375-018-0118-9
PMid:29895954

47. Hellström-Lindberg E, Gulbrandsen N, Lindberg G, Ahlgren T, Dahl IM, Dybedal I, et al. A validated decision model for treating the anaemia of myelodysplastic syndromes with erythropoietin + granulocyte colony-stimulating factor: Significant effects on quality of life. Br J Haematol. 2003;120(6):1037-46. https://doi.org/10.1046/j.1365-2141.2003.04153.x

PMid: 12648074

48. Santini V, Almeida A, Giagounidis A, Gröpper S, Jonasova A, Vey $\mathrm{N}$, et al. Randomized phase III study of lenalidomide versus placebo in RBC transfusion-dependent patients with lower-risk non-del $(5 q)$ myelodysplastic syndromes and ineligible for or refractory to erythropoiesis-stimulating agents. J Clin Oncol. 2016;34(25):2988-96. https://doi.org/10.1200/ JCO.2015.66.0118

PMid:27354480 